\title{
POPULATION INVOLVEMENT IN DEALING WITH LOCAL COMMUNITY PROBLEMS IN THE RURAL AREAS OF LATVIA
}

\author{
Modrite Pelse ${ }^{1}$, professor, Dr.oec.; Liga Svanberga², Mg.oec.; Arianna Todorova ${ }^{3}$, \\ Sabine Berzina ${ }^{4}$, Beate Jurgensone ${ }^{5}$, Raivis Stepans ${ }^{6}$ \\ 1;3-6 Latvia University of Life Sciences and Technologies; ${ }^{2}$ Chair of the association Rural \\ Partnership "Lielupe"
}

\begin{abstract}
The public prefers to express their opinions on the development of the surrounding area, make assessments and comments, as well as participate in surveys. However, the involvement of the public itself in improving the immediate surroundings and in solving the problems of its fellows is not always sufficient. The research aims to determine whether there are differences in public involvement in addressing municipal problems across various population groups within a municipality. The paper presents the results of an extensive survey. The research considered problems within one municipality in Latvia - Jelgava municipality - and analysed the rural territories located in the immediate vicinity of the centre of the municipality as well as those being the furthest from the centre.

The results of the research revealed that young people were most satisfied with their lives in their municipality if their places of residence were closer to the centre of the municipality. The ability to influence the decisions of one's own local government was highly valued by residents in the age group from 26 to 44 years in the rural territories that were in the immediate vicinity of the centre the municipality, yet this possibility was most often rated as weak among the youth living in the most remote rural territories from the centre of the municipality. Population involvement in solving a problem relevant to the society was the most frequently used way when the population requested a municipal employee to solve this problem. A large segment of the society in rural areas admitted that they did nothing, and this passivity was also evident in the group of young people who lived further away from the centre of the municipality. The involvement of the population in national-level public activities across all age groups and territories was quite equal, as the active population were involved in Saeima elections, campaigns for collecting signatures and donating various things.
\end{abstract}

Key words: society, municipality, public involvement, community, rural areas.

JEL code: P35, P25

\section{Introduction}

The 2017 exploratory opinion of the European Economic and Social Committee states that it is necessary to regain the trust of the population in the Member States of the European Union. To achieve it, the approach of community-led local development needs to be applied, which allows for integrated local development, as well as the involvement of citizens and their organizations in addressing current problems. Civil society actors should be perceived as partners, and local young people should be much more involved in community activities.

In 2021 in Latvia, a local government reform is going to be implemented, thereby reducing the number of local governments from 119 to 42 , which means that the centres of municipalities move away from the residents' places of residence. The current issues are how the public currently rates the work of their local governments and how actively they themselves get involved in addressing problems important to their local communities. The research aims to determine whether there are differences in public involvement in addressing municipal problems across various population groups within a municipality. The research carried out a survey, and the problems were analysed based on the opinions of the respondents across different age groups.

No extensive research on Jelgava and Ozolnieki municipalities has not previously been conducted. The research was done in cooperation with the association Rural Partnership "Lielupe" under the EEA and

1 Modrite Pelse, e-mail: modrite.pelse@llu.Iv

2 Liga Svanberga, e-mail: liga@partneribalielupe.Iv

3 Arianna Todorova, e-mail: arianna2009@inbox.Iv 
Norway Grants 2014-2021, the programme Active Citizens Fund. The programme was designed to strengthen the culture of democracy and civic awareness through implementing participatory and educational activities.

\section{Research results and discussion}

At the EU level, the concept of society includes three interrelated dimensions: relationships between residents: mutual trust, social network formation, social diversity acceptance; rooting or belonging: confidence in national institutions, an understanding of justice and strong connection with the state; an understanding of the common good: residents' sense of responsibility for their fellows and willingness to help or solidarity, respect for general societal rules and civic/political participation.

Public participation could be defined as the voluntary and lawful activities of individuals with the aim of influencing decision-making in public administration. It is accompanied by a dialogue between the institutions and the public. In a developed democracy, this dialogue is represented by the active involvement of the public, the highest degree of which is participation in decision-making. The purpose of public participation is to ensure that decisions taken by public administrations are in line with the needs of the public, explained in a timely manner and comprehensible to those whom they apply to. There are a number of benefits of public participation that are overall aimed at improving the quality of legal regulation.

The public administration closest to the population is the local government. A local government is a local administration which, through bodies of representatives elected by citizens - city or municipality council and authorities and institutions established by them, ensures the performance of the functions prescribed by law, as well as the performance of tasks assigned by Cabinet according to the procedures specified by law, and local government voluntary initiatives, observing the interests of the State and of the residents of the relevant administrative territory (On Local Governments, 1994). Several research studies have emphasized the importance of public involvement. The purpose of participation is to ensure that the community itself, which is best aware of the local conditions, provides the municipality with a solution that best suits the interests of sustainable development in the area.

Research studies on the European Union's regional policies emphasize the role of local communities and the importance of their activities. A special programme - LEADER - has been implemented for several decades to develop communities and increase their capacity. One of the basic principles of the LEADER approach is the bottom-up approach, in which the initiative comes from local people, involving them in identifying and tackling problems in their area.

At the beginning of 2021, the Guidelines for a Cohesive and Active Society for 2021-2027 were adopted in Latvia. The guidelines focus on three courses of action: strengthening the national identity, developing a civic society and social integration with the aim of making the population of Latvia more knowledgeable and more active in cooperating and participating in the development of the country (Par saliedetas un ..., 2021). One of the priorities of the national medium-term policy document NDP 2027 is a "united, secure and open society", as mutual trust among citizens is strongly linked with their cooperation and participation skills, which could be achieved through developing civic education and public awareness of democratic processes in the country, including decision-making procedures and the role of a civic society in a democracy (NDP 2027, 2020).

The role of public involvement has been discussed in research papers from a number of perspectives, assessing both the benefits and challenges and determining the importance of strengthening democracy and the civic society. Cooperation between communities has been discussed by Dave G., Freichs L. et al., 2018., while collective cooperation in solving social problems from the business perspective has been 
discussed by Stefan Gold, Judy N. Muthuri and Gerald Reiner. Public involvement is not always direct, and it could be subordinated to the goals of an individual's economic activity, yet it serves the development of the surrounding area, for example, in the field of tourism (Grinberga-Zalite G., Vitolina Z et al., 2017). The role of cooperation among the population, their involvement in the sustainable exploitation of natural resources is the main object of research. Cumming Gabriel, Campbell Lisa, Narwood Carla et al. (2021) have found that people care about their places. We need engagement approaches that reflect and amplify that. Improving the practice of stakeholder engagement, using such techniques, has the potential to help reliably improve resource management outcomes around the globe. Researchers in Latvia have also addressed this problem. Paula L. and Kaufmane D. have concluded that community activities for the preservation of natural resources can be seen as a system that focuses on the rational interaction between local human activities and the environment, seeking to ensure the integrity of specific natural sites and participation in both restoration and rational use of natural resources (Paula L., Kaufmane D., 2020).

Global territorial development goals and the role of local communities, especially public organizations, have been discussed by Olivier Boiral, Inaki Heras-Saizarbitoria, Marie-Christine Brotherton (2019) emphasizing that the lack of educational infrastructure and low enrolment in schools tend to fuel poverty, isolation, and feelings of exclusion among indigenous peoples. However, before addressing more global problems, the basic needs of every citizen should first be met, and they need to be listened to. In addition, the population in a certain area is not homogeneous, and each of the population groups has its own preferences and different needs. Young people focus on how to spend their time in an interesting and meaningful way, whereas seniors are more interested in maintaining their health (Garcia Alexandra A., West Ohueri Chesi et al., 2021).

Young people's trust and belonging to the local community has been researched by scientists at the Institute of Sociology in Taiwan, and the young people's sense of belonging to their territory has been researched by scientists at the University of Bologna (Cicognani E., Martinengo L. et al., 2014.; Chang C.-Y., Wu C.-I., 2020). Nowadays, there is a stereotype about young people as an indifferent part of society who do not care about what is happening around them and who do not get involved in tackling societal problems, which could be characterized by the phrase "do not touch me!", yet at the same time, there are very responsible and active young people who overturn this assumption. The involvement of seniors in social activities, however, is determined by two kinds of factors: personal factors such as age, health status, education, lifestyle, and environmental factors, including the physical and social environment, such as access to public transport, social security etc. (Dahan-Oliel N., Gelinas I. et al., 2008).

A summary of the opinions of scientists reveals that as regards public involvement in solving problems important to the population and the development of a territory, community involvement in development is influenced by many factors such as democratic traditions and societal experience, the distribution of power and the exchange of knowledge between the social agents involved in development processes, the availability of resources and the skills to use them (Paula L., 2019), while the "top-down" approach often prevails in communication between citizens and local governments, which is often based on power relations, is one-sided and formal (Kruzmetra Z., Bite D. et al., 2018). Active public involvement in solving problems important to the society is an important force for shaping government policies aimed at creating a sustainable local community. 


\section{Research methodology}

The present research on the involvement of the public in solving problems and in decision-making in their municipality was based on a survey. The research object was four rural territories of the current Ozolnieki and Jelgava municipalities: Livberze, Ozolnieki, Vilce and Eleja, which on 1 July 2021, after the municipal election, will be amalgamated into one municipality - Jelgava municipality. A rural territory is a territorial unit of a municipality in Latvia. In Latvia, a municipality consists of several rural territories or of rural territories and a town; therefore, a rural territory represents a territorial unit in the administrative division of a municipality. There is a total of 13 rural territories in Jelgava municipality and three rural territories in Ozolnieki municipality. The choice of the four rural territories was determined by the need to identify whether the level of public involvement across different groups of the population differs, depending on the location of the rural territory in the municipality. Ozolnieki and Livberze rural territories, located in the immediate vicinity of the municipality centre - Jelgava city - border it, while Vilce and Eleja rural territories are located further away from the municipality centre, and the territories have no direct border with Jelgava. The centre of Jelgava municipality and leading municipal institutions are located in the city of Jelgava, which is the fourth largest city in Latvia.

The survey was conducted from November 2020 to February 2021. The number of respondents in each rural territory was proportional to the total population, representing $5.2 \%$ of the target population. The total sample size was 456 respondents. Questionnaires and answers to the questions asked were obtained both in face-to-face interviews and via the Internet by using the application docs.google.com, as well as by requesting the population to express their opinions through filling in the questionnaires. The information about the opportunity to participate in the survey was published on the websites of the rural territories, as well as on the project platform kopdare.Iv (we create, do and grow together). The public was informed at the launch event of the project. The survey data obtained were grouped, processed in Excel. The survey distinguished four age groups: young people 16-25, young middle-aged people 26-44, middle-aged people 45-64 and the retirement generation aged over 65 years (senior citizens).

\section{Research results}

Jelgava un Ozolnieki municipalities are among the central municipalities of Latvia, and the centre of the newly formed municipality - Jelgava - is located $45 \mathrm{~km}$ from the capital city of Riga. Information on the rural territories is summarized in Table 1.

Table 1

Locations of the rural territories analysed, their populations, areas and distances to the centre of the municipality and the capital city in 2020

\begin{tabular}{|l|c|c|c|c|c|c|}
\hline $\begin{array}{c}\text { Rural } \\
\text { territory }\end{array}$ & $\begin{array}{c}\text { Territory } \\
\text { borders on } \\
\text { municipality } \\
\text { centre }\end{array}$ & Population & $\begin{array}{c}\text { Area, } \\
\mathbf{k m} \mathbf{2}^{2}\end{array}$ & $\begin{array}{c}\text { Population } \\
\text { density } \\
\text { people/km2 }\end{array}$ & $\begin{array}{c}\text { Distance } \\
\text { to Jelgava, } \\
\mathbf{k m}\end{array}$ & $\begin{array}{c}\text { Distance } \\
\text { to Riga, } \\
\mathbf{k m}\end{array}$ \\
\hline Ozolnieki & yes & 4154 & 7.88 & 527.15 & 6 & 37 \\
\hline Livberze & yes & 1971 & 146.40 & 13.46 & 15 & 60 \\
\hline Eleja & no & 1897 & 66.80 & 28.39 & 28 & 68 \\
\hline Vilce & no & 1413 & 127.17 & 11.11 & 40 & 80 \\
\hline
\end{tabular}

Source: authors' own compilation based on data on Jelgava un Ozolnieki municipalities, CSB 2020

Ozolnieki rural territory is the most populous one, relatively more young families live in it, and it is located the closest to the capital Riga where many of its residents also have jobs. Good transport 
infrastructure is available - both rail and motorways. Livberze and Eleja rural territories have good road infrastructure, as well as railway infrastructure that is not used for passenger transport. Vilce rural territory is located the farthest from the centre of the municipality and the capital Riga, while railway infrastructure is not available in it.

The satisfaction of residents with the work of their local governments is shown in Figure 1 . The residents could rate it on a scale from "fully satisfied or satisfied" that is designated by "yes" to "rather dissatisfied or dissatisfied" that is designated by "no", while those for whom it was difficult to rate the work of the local government could choose the reply option "hard to say".

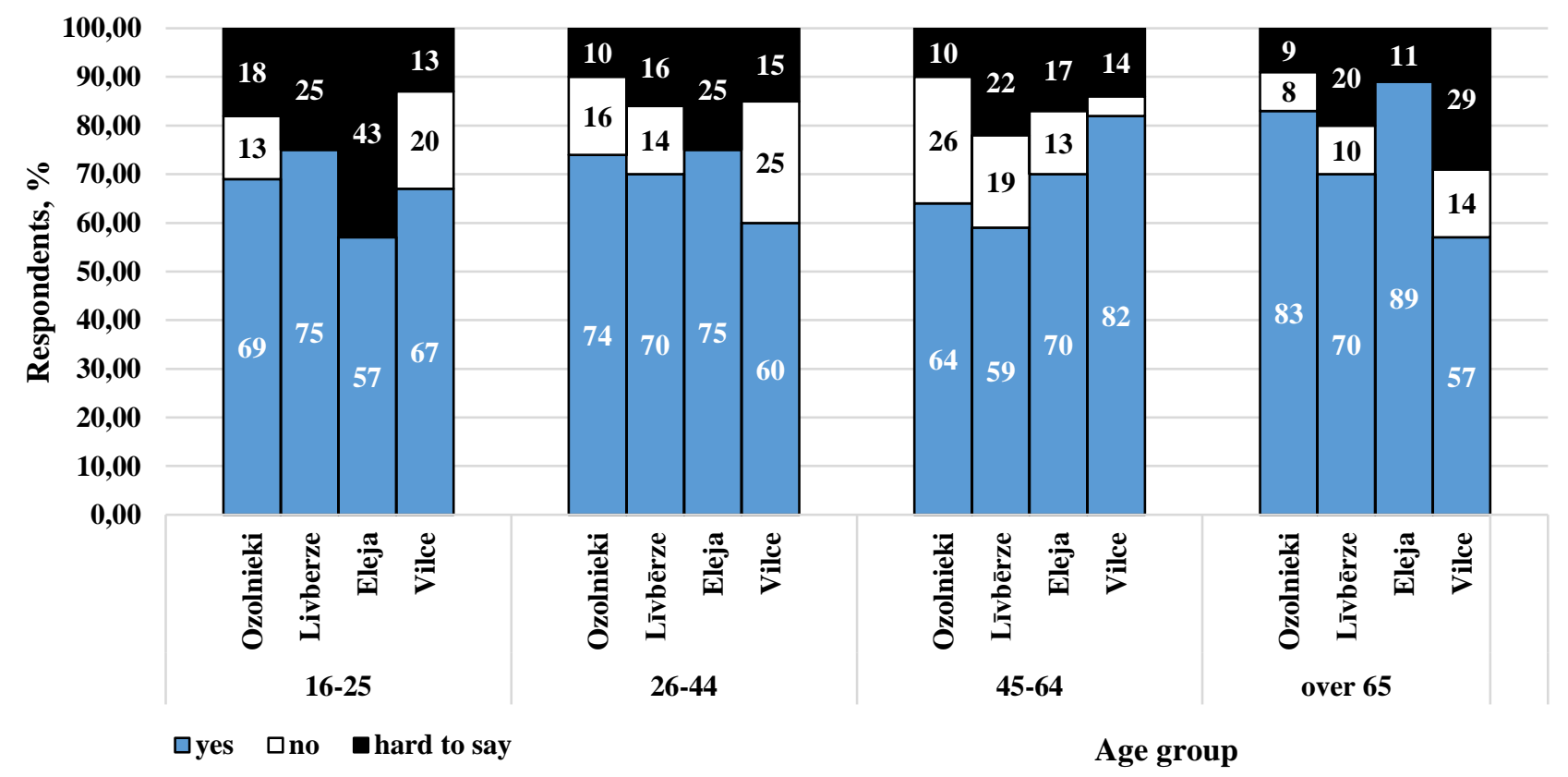

Source: authors' construction based on the survey data, 2021

Fig. 1. Percentage breakdown of respondent replies to the question about resident satisfaction with the work of their local governments by rural territory and age group

The level of satisfaction with life in the rural territories, which was influenced the work of the local government, was overall rated as positive across all the age groups, and most of the population rated it as good. Two age groups could be emphasized with regard to the locations of the rural territories. Young people were more satisfied with the work of their local governments in the rural territories located the closest to the centre of the municipality, $69 \%$ in Ozolnieki and $75 \%$ in Livberze, than in the rural territories located the furthest, only $57 \%$ in Eleja and $20 \%$ in Vilce. The second age group was the middle generation aged 45-64, and the satisfaction with the work of the local government was higher in the most remote rural territories, 70-82 \%. However, the residents satisfied the most with the work of their local government were found in Eleja rural territory in the age group over 65 with $89 \%$ of the total respondents, while in the second most remote rural territory Vilce, senior citizens were the least satisfied: $14 \%$ were not satisfied, while $29 \%$ had no opinion at all.

Figure 1 summarized the attitudes of the residents to and their ratings of the work of the local government, its institutions, the council and the executive body of the municipality, but how much can the residents themselves influence it? Are local residents involved in municipal decision-making and do they have an opportunity to influence the decisions? The results of the survey on these issues are summarized in Figure 2. 


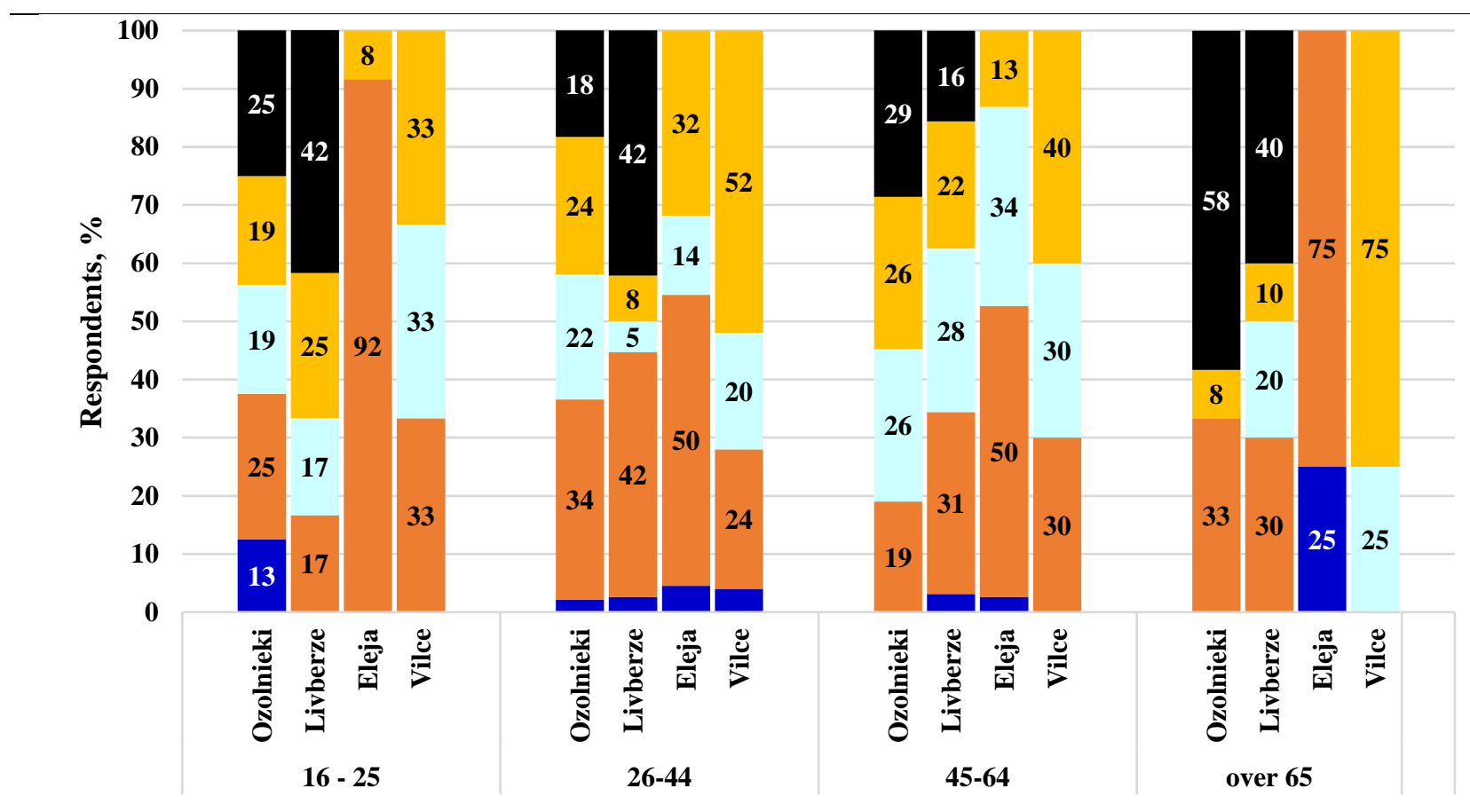

- excellent good average weak $\square$ hard to say

Age group

Source: authors' construction based on the survey data, 2021

Fig. 2. Percentage breakdown of respondent replies to the question about an opportunity for residents to participate in municipal decision-making by rural territory and age group

The opportunity to get involved in municipal decision-making was rated on average higher in the middleaged groups, i.e. those aged 26-44 and 45-64. The opportunity was rated lower in the group of young people living in the rural territories located the closest to the centre of the municipality than in the most remote rural territories. The participation of the elderly in municipal decision-making was very different, with 30-33\% respondents living in the rural territories the closest to the centre rating this opportunity as good. The situation was completely different in remote rural territories: in Eleja senior citizens rated this opportunity as only good or even excellent, whereas in Vilce $75 \%$ rated it as weak, and in this rural territory the elderly rated overall municipal performance as the lowest.

The researched assessed the activity of the population in the last three years, and totally two categories of activities were put forward: "for the benefit of society", i.e. the activities for solving the problems of another individual or population group in the municipality and "national level activities" representing various kinds of activities (Table 2). 


\section{Population activity during the last three years, frequency of Top 3 activities}

\begin{tabular}{|c|l|c|l|c|}
\hline \multirow{2}{*}{ No. } & $\begin{array}{l}\text { Activities to solve the problems of } \\
\text { Societal groups in the municipality }\end{array}$ & \multirow{2}{*}{ Frequency } & Various activities in the last three years & \multirow{2}{*}{ Frequency } \\
\cline { 2 - 4 } & \multicolumn{1}{|c|}{ for the benefit of society } & & \multicolumn{1}{|c|}{ national level activities } & 15 \\
\hline $\mathbf{1}$ & Meeting with a local government deputy & 0 & Participation in national elections & 13 \\
\hline $\mathbf{2}$ & Meeting with a local government official & 9 & Signing up for an initiative on manabalss.lv & 0 \\
\hline $\mathbf{3}$ & Meeting with a Saeima deputy & 0 & Voluntary work & 1 \\
\hline $\mathbf{4}$ & $\begin{array}{l}\text { Meeting with a national institution } \\
\text { employee }\end{array}$ & 0 & Holding a picket & 0 \\
\hline $\mathbf{5}$ & Meeting with a sectoral minister & 0 & Participation in a picket & 1 \\
\hline $\mathbf{6}$ & Participation in public consultation & 6 & Participation in joint work & 7 \\
\hline $\mathbf{7}$ & $\begin{array}{l}\text { Collection of signatures in the } \\
\text { municipality }\end{array}$ & 5 & Donation of things & 1 \\
\hline $\mathbf{8}$ & Participation in municipal elections & 14 & Donation of food & 6 \\
\hline $\mathbf{9}$ & Involvement in local level administration & 1 & Donation of money & 2 \\
\hline $\mathbf{1 0}$ & Participation in online voting & 6 & Ethical, environment-friendly principles & 2 \\
\hline $\mathbf{1 1}$ & $\begin{array}{l}\text { Purchase of goods/services produced in } \\
\text { the municipality }\end{array}$ & 1 & Involvement in not a single field of activity & 2 \\
\hline $\mathbf{1 2}$ & Participation in not a single activity & $\mathbf{4}$ & & 2 \\
\hline
\end{tabular}

Source: authors' construction based on the survey data, 2021

The Top 3 activities for each age group and in each rural territory are summarized in Table 3 . In order to make the table easier to read, each the same activity and its No. from Table 2 was coloured in different colours.

Table 3

Top 3 activities carried out by residents in Ozolnieki, Livberze, Eleja and Vilce
rural territories during the last three years

\begin{tabular}{|c|c|c|c|c|c|c|c|c|c|c|c|c|c|c|c|c|c|c|c|c|c|c|c|c|}
\hline \multirow{3}{*}{$\begin{array}{c}\text { Age group } \\
16-25 \\
\end{array}$} & \multicolumn{6}{|c|}{ Ozolnieki } & \multicolumn{6}{|c|}{ Livberze } & \multicolumn{6}{|c|}{ Eleja } & \multicolumn{6}{|c|}{ Vilce } \\
\hline & \multicolumn{3}{|c|}{$\begin{array}{c}\text { for the } \\
\text { benefit of } \\
\text { society }\end{array}$} & \multicolumn{3}{|c|}{$\begin{array}{c}\text { national } \\
\text { level } \\
\text { activities }\end{array}$} & \multicolumn{3}{|c|}{$\begin{array}{c}\text { for the } \\
\text { benefit of } \\
\text { society }\end{array}$} & \multicolumn{3}{|c|}{$\begin{array}{c}\text { national } \\
\text { level } \\
\text { activities }\end{array}$} & \multicolumn{3}{|c|}{$\begin{array}{c}\text { for the } \\
\text { benefit of } \\
\text { society }\end{array}$} & \multicolumn{3}{|c|}{$\begin{array}{c}\text { national } \\
\text { level } \\
\text { activities }\end{array}$} & \multicolumn{3}{|c|}{$\begin{array}{c}\text { for the } \\
\text { benefit of } \\
\text { society }\end{array}$} & \multicolumn{3}{|c|}{$\begin{array}{c}\text { national } \\
\text { level } \\
\text { activities }\end{array}$} \\
\hline & 6 & 8 & 10 & 1 & 2 & 7 & 8 & 10 & 12 & 1 & 0 & 9 & 8 & 9 & 10 & 1 & 2 & 4 & 6 & 7 & 12 & 1 & 2 & 9 \\
\hline & 2 & 6 & 8 & 1 & & 7 & 7 & 8 & 10 & & 2 & 9 & 2 & & 8 & 1 & 1 & 8 & 2 & 7 & 8 & 1 & 2 & 9 \\
\hline $45-64$ & 2 & 6 & 8 & 1 & 2 & 9 & 2 & 8 & 12 & 1 & 2 & 7 & 6 & 8 & 12 & 1 & 2 & 10 & 2 & 7 & 8 & 1 & 2 & 9 \\
\hline over 65 & 2 & 10 & $*$ & 6 & 7 & 11 & 2 & 8 & 10 & 1 & 2 & 11 & 2 & 8 & $*$ & 1 & 7 & 10 & 7 & 8 & 11 & 1 & 2 & 7 \\
\hline
\end{tabular}

Note: figures in the table correspond to No. from Table 2 for each activity category

\section{Source: authors' construction based on the survey data, 2021}

Overall, there were quite small differences in public participation in public activities at the national level between age groups and the locations of the rural territories, and mostly residents in rural areas were active in the choice of national legislative power - participated in parliamentary elections - and were ready to express their views through signature campaigns, e.g. on manabalss.Iv. The next most popular group of activities was "donation campaigns", donating both various things (not food) and money. In addition, donating things was popular across all the age groups, whereas donating money was preferred by young people and the working population.

To get involved in tackling the needs of an individual or a larger segment of society in the rural territories analysed, the most active residents preferred to choose their local government - they participated in municipal elections, except for young people in the remote rural territory of Vilce. The second most common activity was a meeting with a municipal official to address current problems. However, this activity was not popular among young people. The third most popular group of activities was participation in a public 
discussion on a problem and/or a collection of signatures, although the activities had a locally specific "frequency" at the rural territory level, which was most likely determined by the fact that such activities were carried out in the municipality.

\section{Conclusions, proposals, recommendations}

1) Scientific research studies have recognized that the involvement of citizens in addressing problems of public importance is a significant force. It also contributes to a stable and effective local government, satisfied residents and cooperation-driven development in the territory. It is also emphasized that the social activism of local communities and each individual is influenced by their traditions, experience, skills and knowledge as well as other factors, yet a lack of education can contribute to social isolation and exclusion. It is pointed out that each age group has its own needs and interests.

2) The research results showed that young people were most satisfied with their lives in their municipality if their places of residence were closer to the centre of the municipality. Although they did not overestimate their ability to influence local government decisions, yet in remote areas the young people even rated this opportunity as weak.

3) The opinions of the elderly differed and were in the range from strongly positive to negative, and for some of them it was difficult to judge what was happening in the municipality at all, and the opinions were mostly influenced by local events in the municipality.

4) The ability to influence the decisions made by the local government was highly rated by residents aged 26 to 44 in the rural territories located in the immediate vicinity of the centre of the municipality. However, those representing the middle generation aged 45 to 64 and living in the rural territories located the furthest from the centre of the municipality were more satisfied with the work of the municipality.

5) There were small differences in the involvement of the public in solving their local problems across various societal groups within a municipality. Overall, the activity of the public focused on expressing an opinion: voting in an election, participating in surveys and polls, collecting signatures, or participating in donation campaigns (things and money). Several residents in rural areas noted that they were not active and did not participate in any social activities; this was observed across all the age groups, except for the young middle generation aged 24-44, who were the most socially active segment of the population in the rural territories.

\section{Acknowledgements}

The paper was supported by the project Increasing Participation and Civic Activity in Jelgava and Ozolnieki Municipalities under the EEA and Norway Grants 2014-2021, the programme Active Citizens Fund.

\section{Bibliography}

1. Dahan-Oliel, N., Gelinas, I., Mazer, B. (2008). Social Participation in the Elderly: What does the Literature Tell us? Critical Reviews in Physical and Rehabilitation Medicine, Vol.20 (2), pp. 159-176.

2. Dave, G., Frerichs, L., Jones, J., Kim, M., Schaal, J., Vassar, S., Varma, D., Striley, C., Ruktanonchai, C., Black, A., Hankins, J., Lovelady, N., Cene, C., Green, M., Young, T., Tiwari, S., Cheney, A., Cottler, L., Sullivan, G., Brown, A., Burke, J., Corbie-Smith, GL. (2018). Conceptualizing Trust in Community-academic Research Partnerships Using Concept Mapping Approach: A multi-CTSA study. Evaluation and Program Planning, Volume 66, February 2018, pp. 70-78.

3. Chang, C.-Y., Wu, C.-I. (2020). The Friend Influence in Network Neighbourhood Context on Adolescents' Community Attachment. International Journal of Adolescence and Youth, Vol.25, Issue 1, pp. 536-550.

4. Cicognani, E., Martinengo, L., Albanesi, C., Piccoli, N.D., Rollero, C. (2014). Sense of Community in Adolescents from Two Different Territorial Contexts: The Moderating Role of Gender and Age. An International and Interdisciplinary Journal for Quality-of-Life Measurement: Social Indicators Research. Volume 119, Issue 3, December 2014, pp. 1663-1678. 
5. Central Statistical Bureau: Population Number and Change (2021). Retrieved: https://www.csb.gov.Iv/Iv/statistika/statistikas-temas/iedzivotaji/iedzivotaju-skaits/galvenieraditaji/iedzivotaju-skaits-republikas-pilsetas Access: 07.02.2021.

6. Cumming, G., Campbell, L., Norwood, C., Ranger, S., Richardson, P, Sanghera, A. (2021). Putting Stakeholder Engagement in its Place: How Situating Public Participation in Community Improves Natural Resource Management Outcomes. GeoJournal. Retrieved: https://www.researchgate.net/publication/348520459_Putting_stakeholder_engagement_in_its_place_how_sit uating_public_participation_in_community_improves_natural_resource_management_outcomes Access: 17.02.2021.

7. Garcia Alexandra, A., Ohueri, C.W,. Garay, R., Guzman, M., Hanson, K., Vasquez, M., Zuniga, J., Tierney, W. (2021). Community Engagement as a Foundation for Improving Neighborhood Health. Retrieved: https://onlinelibrary.wiley.com/doi/epdf/10.1111/phn.12870 Access: 17.02.2021.

8. Grinberga-Zalite, G., Vitolina, Z., Rivza, B. (2017). Knowledge and Skills Transfer for Sustainable Rural Tourism in the Baltic Sea Countries. Proceedings book, Berlin, Germany, Vol.2, pp. 403-407.

9. Kruzmetra, Z., Bite, D., Kronberga, D. (2018). Government-citizen Communication in Rural Municipalities in Latvia. Economics Science for Rural Development, proceedings, No 48, Jelgava, 9- 11 May 2018, pp. 154-162.

10. Boiral, O., Heras-Saizarbitoria, I., Brotherton, M.C. (2019). Corporate Sustainability and Indigenous Community Engagement in the Extractive Industry. Journal of Cleaner Production, Vol.235 pp.701-711.

11. On Local Governments (1994). Law of the Republic of Latvia. Retrieved: https://likumi.lv/ta/id/57255-parpasvaldibam. Access: 14.01.2021.

12. Par saliedetas un pilsoniski aktivas sabiedribas attistibas pamatnostadnem 2021.-2027.gadam (Guidelines for a Cohesive and Active Society for 2021-2027) (2021). Order No. 72 of the Cabinet of the Republic of Latvia. Retrieved: https://likumi.Iv/ta/id/320841-par-saliedetas-un-pilsoniski-aktivas-sabiedribas-attistibaspamatnostadnem-20212027-gadam. Access: 15.02.2021.

13. Paula, L. (2019). Community Involvement in Local Development: Theoretical Analysis of Community Development Approaches. "Rural development 2019: Research and innovation for bioeconomy": proceedings, Kaunas, Lithuania, 27-29 September 2019, pp. 451-457.

14. Paula, L. and Kaufmane, D. (2020). Community Resilience and Initiatives for the Preservation of Natural Resources: Leader Projects in Latvia. SGEM 2020: proceedings Environmental Economics, Albena, Bulgaria, Vol. 20, Issue 5.2, pp. 11.-120.

15. NDP 2027 (2020) National Development Plan for 2021-2027. Retrieved: https://www.pkc.gov.Iv/sites/default/files/inline-files/NAP2027_ENG_2.pdf. Access: 12.12.2020.

16. Gold S., Muthuri J.N., Reiner G.,(2018). Collective Action for Tackling "Wicked" Social Problems: A System Dynamics Model for Corporate Community Involvement. Journal of Cleaner Production, Volume 179, 1 April 2018, pp. 662-673. 